\title{
Editorial: The pursuit of new concretes
}

\author{
Peter C. Hewlett BSC, PhD, LLD, CChem, CSci, FRSC, FIM, FICT, \\ FConcSoc \\ Professor, University of Dundee, UK; R and D Director to the \\ David Ball Group
}

The task of achieving sustainability is on the global agenda, and allied to it are issues of efficiency and low energy use. Construction and concrete are not exempted and, as a result, new concretes are being developed alongside new cements and related composite materials. In this issue we have three papers that exemplify this themed trend.

The paper by Jones et al. (2016) details extremely lightweight foamed concrete with densities down to $150 \mathrm{~kg} / \mathrm{m}^{3}$ without the associated problems of instability. Such concretes may well have practical applications.

The second paper, by Khatib et al. (2016), deals with using what otherwise would be a discarded material, namely simulated desulfurised waste. This material in combination with cement and slag/ cement combinations can result in concrete of adequate mechanical properties.

The third themed paper, by Black and Purnell (2016), addresses the issue of carbon dioxide $\left(\mathrm{CO}_{2}\right)$ pricing. A range of mix designs that span some 20-100 Mpa shows that reducing the carbon footprint also reduces the cost of the concrete. However, the cheaper the mixes did not have the lowest embodied carbon dioxide (ECD) on the basis of ECD per unit of strength.

The other two papers in issue 11 are significant from a performance/efficiency standpoint. The paper by Zhang (2016) concerns the use of fibre-reinforced materials bonded externally to concrete members to impart flexural strength. Understanding the role of bond and its dependency on peel and shear are covered. The work has resulted in being able to predict bond strength under shear/peeling fracture. Such predictions agree with tested specimens.

The paper by Yang and Yi (2016) concerns the use of lightweight aggregate based on expanded clay granules as secondary aggregates. Two types of concrete were studied from a stresscrack mouth opening displacement standpoint under direct tension. There is a specimen size effect phenomenon. The underlying mechanisms are considered and accepted models mentioned.

The reader may wish to refer to related themed items in our sister publication, Advances in Cement Research, volume 28, issue 4, April 2016, that looks at innovations from cement's standpoint (Bernal et al., 2016; Camacho-Ballesta et al., 2016; Kaufmann et al., 2016; Mas et al., 2016; Siauciunas et al., 2016; Suryanto et al., 2016; Yilmaz et al., 2016).

\section{REFERENCES}

Bernal SA, San Nicolas R, van Deventer JSJ and Provis JL (2016) Alkali-activated slag cements produced with a blended sodium carbonate/sodium silicate activator. Advances in Cement Research 28(4): 262-273, http://dx.doi.org/10.1680/jadcr.15.00013.

Black $L$ and Purnell P (2016) Is carbon dioxide pricing a driver in concrete mix design? Magazine of Concrete Research 68(11): 561-567, http://dx.doi.org/10.1680/jmacr.15.00018.

Camacho-Ballesta C, Zornoza E and Garcés P (2016) Performance of cement-based sensors with CNT for strain sensing. Advances in Cement Research 28(4): 274-284, http://dx.doi.org/10.1680/ adcr.14.00120.

Jones MR, Ozlutas K and Zheng L (2016) Stability and instability of foamed concrete. Magazine of Concrete Research 68(11): 542-549, http://dx.doi.org/10.1680/macr.15.00097.

Kaufmann J, Winnefeld F and Lothenbach B (2016) Stability of ettringite in CSA cement at elevated temperatures. Advances in Cement Research 28(4): 251-261, http://dx.doi.org/10.1680/ jadcr.15.00029.

Khatib JM, Mangat PS and Wright L (2016) Mechanical and physical properties of concrete containing FGD waste. Magazine of Concrete Research 68(11): 550-560, http://dx.doi. org/10.1680/macr.15.00092.

Mas MA, Monzó J, Payá J, Reig L and Borrachero MV (2016) Ceramic tiles waste as replacement material in Portland cement. Advances in Cement Research 28(4): 221-232, http:/ dx.doi.org/10.1680/jadcr.15.00021.

Siauciunas R, Baltakys K, Gendvilas R and Prichockiene E (2016) Synthesis of low-energy cement based on $\alpha-\mathrm{C}_{2} \mathrm{SH}$. Advances in Cement Research 28(4): 241-250, http://dx.doi.org/10.1680/ jadcr.15.00024.

Suryanto B, Wilson SA, McCarter WJ and Chrisp TM (2016) Self-healing performance of engineered cementitious composites under natural environment exposure. Advances in Cement Research 28(4): 211-220, http://dx.doi.org/10.1680/ jadcr.15.00022.

Yang K-H and Yi S-T (2016) Tests on direct tensile characteristics of expanded clay lightweight aggregate concrete. Magazine of Concrete Research 68(11): 581-592, http://dx.doi.org/10.1680/ jmacr.15.00077.

Yilmaz M, Tokyay M and Yaman IO (2016) Cement production by cement-bonded wood particleboard wastes. Advances in Cement Research 28(4): 233-240, http://dx.doi.org/10.1680/ jadcr.15.00023.

Zhang W (2016) Experimental study on shear-peeling bond strength between a CFRP plate and concrete. Magazine of Concrete Research 68(11): 568-580, http://dx.doi.org/10.1680/ jmacr.15.00162. 